\title{
Evaluation of 2-deoxy-D-glucose as a chemotherapeutic agent: mechanism of cell death
}

\section{RL Aft*, ${ }^{*, 2}$, FW Zhang' and D Gius ${ }^{3}$}

'Department of Surgery, Alvin J. Siteman Cancer Center, Washington University School of Medicine, St. Louis, Missouri, MO 631 I0, USA; ${ }^{2}$ John Cochran Veterans Administration Hospital, St. Louis, Missouri, MO 631 10, USA; ${ }^{3}$ National Cancer Institute, Radiation Oncology Branch, National Institute of Health, Bethesda, Maryland, MD 20892, USA

Nutrient deprivation has been shown to cause cancer cell death. To exploit nutrient deprivation as anti-cancer therapy, we investigated the effects of the anti-metabolite 2-deoxy-D-glucose on breast cancer cells in vitro. This compound has been shown to inhibit glucose metabolism. Treatment of human breast cancer cell lines with 2-deoxy-D-glucose results in cessation of cell growth in a dose dependent manner. Cell viability as measured by the 3-(4,5-dimethylthiazol-2-yl)-2,5-diphenyl tetrazolium bromide conversion assay and clonogenic survival are decreased with 2-deoxy-D-glucose treatment indicating that 2-deoxy-D-glucose causes breast cancer cell death. The cell death induced by 2-deoxy-D-glucose was found to be due to apoptosis as demonstrated by induction of caspase 3 activity and cleavage of poly (ADP-ribose) polymerase. Breast cancer cells treated with 2-deoxy-D-glucose express higher levels of Glut I transporter protein as measured by Western blot analysis and have increased glucose uptake compared to non-treated breast cancer cells. From these results we conclude that 2deoxy-D-glucose treatment causes death in human breast cancer cell lines by the activation of the apoptotic pathway. Our data suggest that breast cancer cells treated with 2-deoxy-D-glucose accelerate their own demise by initially expressing high levels of glucose transporter protein, which allows increased uptake of 2-deoxy-D-glucose, and subsequent induction of cell death. These data support the targeting of glucose metabolism as a site for chemotherapeutic intervention by agents such as 2-deoxy-D-glucose.

British Journal of Cancer (2002) 87, 805 -8I2. doi:I0.1038/sj.bjc.6600547 www.bjcancer.com

(C) 2002 Cancer Research UK

Keywords: apoptosis; breast cancer; glucose metabolism; tumour metabolism

Tumour cells are dependent on glycolysis to support their metabolic requirements. Even under aerobic conditions, tumour cells continue to rely on glycolysis rather than oxidative phosphorylation (Warburg effect) resulting in high glucose requirements to generate energy and support metabolic function (Warburg, 1956; Weber, 1977). Malignant transformation of cultured cells with oncogenes or onco-viruses results in an absolute increase in the amount of glucose transported into the cell. This is mediated by transcriptional activation of the Glutl glucose transporter gene resulting in increased levels of glucose transporter mRNA and protein (Birnbaum et al, 1987; Flier et al, 1987). Many human cancers have been found to express elevated levels of the Glut1 glucose transporter compared to normal tissues (Yamamoto et al, 1990; Younes et al, 1996). In human breast cancers, high Glut1 expression tends to correlate with tumours having high proliferative activity and histological score (Brown and Wahl, 1993; Younes et al, 1995). These findings have led to the hypothesis that increased glucose uptake may represent an important regulatory point in the maintenance of growth and synthetic activity of malignant cells and suppression of apoptosis (Greiner et al, 1994; Kan et al, 1994; Bentley et al, 2001; Vander Heiden et al, 2001).

* Correspondence: Rebecca Aft; Department of Surgery, Washington University Campus Box 8109, 660 South Euclid Avenue, St. Louis, MO 63110, USA. E-mail: aftr@msnotes.wustl.edu

Received 28 December 200 I; revised 5 June 2002; accepted 22 July 2002
Experimental conditions of glucose-deprivation have been demonstrated to cause apoptosis in many transformed cell lines (Shim et al, 1998). For example, glucose-deprivation in an interleukin 3 dependent lymphoma cell line and the MCF7/ADR breast cancer cell line have been found to cause apoptosis (Kan et al, 1994; Lee et al, 1997). Multiple related mechanisms may be involved in glucose-deprivation induced signalling including the activation of kinases (mitogen activation protein kinase, c-Jun Nterminal kinase, Lyn kinase) (Galoforo et al, 1996; Gupta et al, 1997; Liu et al, 1997; Lee et al, 1998), change in the redox state of the cell (Blackburn et al, 1999; Spitz et al, 2000), or generation of free radicals (Nomura et al, 1999).

Glucose-deprivation can be mimicked with glucose antagonists. Glucose analogues have been found to profoundly inhibit glucose metabolism in cancer cells in vitro and in vivo (Ball et al, 1957; Laszlo et al, 1958; Kaplan et al, 1990a). Of the many glucose analogues which have been investigated, 2-deoxy-D-glucose (2DG) has proved very effective in the inhibition of glucose metabolism and ATP production (Laszlo et al, 1960; Jain et al, 1985; Kaplan et al, 1990a). 2DG is a structural analogue of glucose differing at the second carbon atom by the substitution of hydrogen for a hydroxyl group (Figure 1A) and appears to selectively accumulate in cancer cells by metabolic trapping (Gallagher et $a l, 1978$ ) due to increased uptake (Waki et al, 1998; RivenzonSegal et al, 2000), high intracellular levels of hexokinase or phosphorylating activity (Kaplan et al, 1990a; Arora et al, 1992; Waki et al, 1997; Aloj et al, 1999), and low intracellular levels of phos- 
A
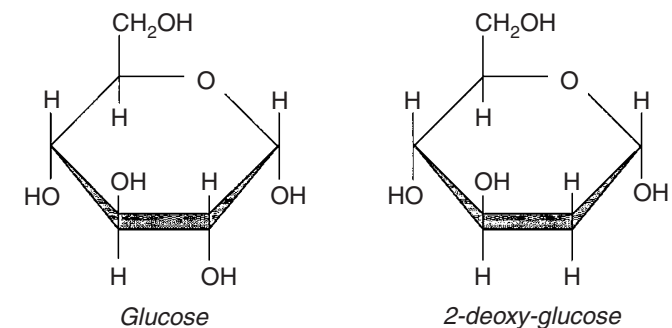

B

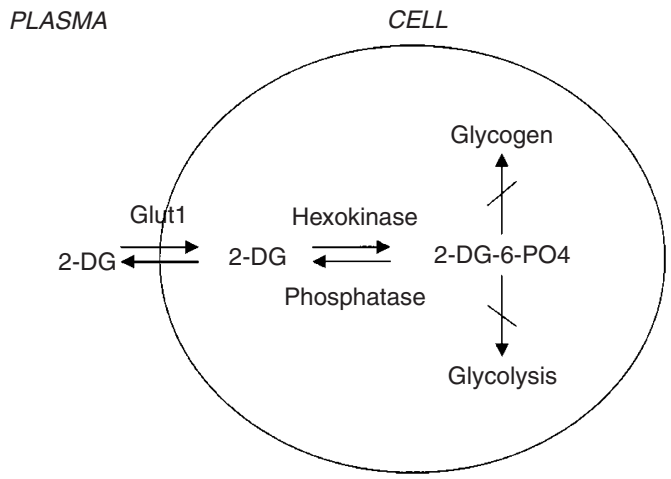

Figure I (A) Structural comparison of glucose and 2-deoxy-D-glucose 2DG and glucose differ at the second carbon. (B) Schematic diagram of 2DG action. 2DG enters the cell through the glucose transporter and is phosphorylated by hexokinase. Due to low levels of intracellular phosphatase, 2-DG-PO $\mathrm{P}_{4}$ is trapped in the cell. 2-DG-PO ${ }_{4}$ is unable to undergo further metabolism. High intracellular levels of 2-DG-6-PO 4 cause allosteric and competitive inhibition of hexokinase. This results in inhibition of glucose metabolism.

phatase (Kern and Norton, 1987; Nelson et al, 1996) (Figure 1B). Cell killing caused by 2DG has been described in several cell lines (Jain et al, 1985; Kaplan et al, 1990b; Nomura et al, 1999; Ko et al, 2001).

To exploit glucose metabolism of cancer cells as a therapeutic target, we have investigated the effects of $2 \mathrm{DG}$ in human breast cancer cells. In the described series of experiments, we demonstrate that 2DG inhibits breast cancer cell growth, clonogenicity, and causes cell death through apoptosis. Breast cancer cells treated with 2DG express higher levels of the Glut1 transporter protein and exhibit increased uptake of glucose, indicating that cells might enhance their death in response to 2DG treatment. These results support targeting glucose metabolism as a target site for chemotherapeutic intervention using compounds such as 2DG since the initial response of increased transporter expression and glucose uptake results in accelerated cellular demise.

\section{MATERIALS AND METHODS}

\section{Cell culture}

Cell lines SkBr3, MCF-7, BT474, and MDA/MB468, all obtained from ATCC, were grown in RPMI-1640 media supplemented with $10 \%$ heat inactivated fetal calf serum, penicillin (100 units $\left.\mathrm{ml}^{-1}\right)$ streptomycin $\left(100 \mu \mathrm{g} \mathrm{ml}^{-1}\right)$, and amphotericin $\mathrm{B}\left(0.25 \mu \mathrm{g} \mathrm{ml}^{-1}\right)$ in a humidified atmosphere of $5 \% \mathrm{CO}_{2}$ and $95 \%$ air at $37^{\circ} \mathrm{C}$. For most experiments, cells were seeded at $2.5 \times 10^{6}$ cells per 10 $\mathrm{cm}$ diameter tissue culture plate 2 days prior to use.

\section{Clonogenic survival assay}

Cells were plated at 4000 cells well $^{-1}$ in a 96 -well plate, allowed $24 \mathrm{~h}$ to attach and subsequently exposed for $4 \mathrm{~h}$ to 2DG. Cells were trypsinised, counted, and replated at 400 cells per $60 \mathrm{~mm}$-diameter culture dish and incubated undisturbed for 14 days at $37^{\circ} \mathrm{C}$ in a humidified incubator. Colonies were counted after fixing with methanol: acetic acid (3:1) and staining with $0.25 \%$ crystal violet. Colonies containing more than 25 cells were scored as positive. Each data point was performed in triplicate. Data were normalised to sham treated control cell plating efficiencies. Plating efficiency of sham treated cells was $38-50 \%$, calculated as the number of colonies observed divided by the number of trypsinised cells plated. Error bars represent the range of values. Each data point represents the average of three samples.

\section{Measurement of $\left[{ }^{14} \mathrm{C}\right] 3-\mathrm{O}-$-methyl-glucose (3-O-MG) uptake}

One to two days prior to the experiment, cells were plated in triplicate at $10^{4}$ cells $\mathrm{cm}^{-2}$ in 6 -well plates $(35 \mathrm{~mm}$ diameter wells). Cells were incubated with $8 \mathrm{mM} 2 \mathrm{DG}$ for $4 \mathrm{~h}$, rinsed with warm PBS, and $950 \mu \mathrm{l}$ of warm uptake media $(128 \mathrm{mM} \mathrm{NaCl}, 4.7 \mathrm{mM}$ $\mathrm{KCl}, \quad 1.25 \mathrm{~mm} \quad \mathrm{MgSO}_{4}, \quad 10 \mathrm{mM} \quad \mathrm{NaH}_{2} \mathrm{PO}_{4}, 1.25 \mathrm{mM} \mathrm{CaCl}_{2}$, $\mathrm{pH}$ 7.4) was added to each well. Where indicated, $50 \mu \mathrm{M}$ of cytochalasin B was added in the warm uptake media (Hamrahian et al, 1999). Plates were incubated at $37^{\circ} \mathrm{C}$ for $6 \mathrm{~min}$ and subsequently $50 \mu \mathrm{l}$ of $\left[{ }^{3} \mathrm{H}\right] 3-\mathrm{O}$-methyl-glucose was added (1 mM 3-O-methylglucose, $20 \mu \mathrm{Ci} \mathrm{ml}{ }^{-1}$ of $\left[{ }^{14} \mathrm{C}\right] 3-\mathrm{O}$-methyl-glucose). Incubation was continued for the indicated times. The reactions were stopped by the addition of cold PBS. The cells were washed five times with cold PBS and lysed with $1 \mathrm{~mm} \mathrm{NaOH}$. Ten microlitres from each sample was used for protein concentration analysis (Bio-Rad DC Protein Assay). Scintillation fluid was added to the remainder of the sample for scintillation counting. Glucose uptake was calculated as $\mu$ moles uptake per $\mu$ g protein. 3-O-methyl-D- $\left[{ }^{14} \mathrm{C}\right]$ glucose $\left(56 \mathrm{mCi} \mathrm{mmol}^{-1}\right)$ was purchased from Amersham Corp.

\section{MTT assay}

Cells (2500 per well) were plated in quadruplicate in 96-well culture plates. Following cell adherence $(24-48 \mathrm{~h})$, experimental media containing 2DG or control media was added and incubation continued for the indicated times at $37^{\circ} \mathrm{C}$. MTT $\left(0.5 \mathrm{mg} \mathrm{ml}^{-1}\right.$ in PBS) was added to each well and incubation continued at $37^{\circ} \mathrm{C}$ for an additional $4 \mathrm{~h}$. The media was then discarded and $200 \mu \mathrm{l}$ of DMSO was added to each well to solubilise the coloured formazan product. Absorbance was read at $550 \mathrm{~nm}$ on a scanning microtiter spectrophotometer plate reader (Bio-Rad) after agitating the plated for $5 \mathrm{~min}$ on a shaker. All data is expressed relative to untreated cells in the same experiment which are standardised to 100\% (Carmichael et al, 1987).

\section{Glut1 protein Western blot analysis}

Cells were plated at $10^{4}$ cells $\mathrm{cm}^{-2}$ and grown in the presence of 2DG for the times indicated in the figures. At each time point, cells were collected, and lysed by the addition of HER buffer $(250 \mathrm{mM}$ sucrose, $10 \mathrm{~mm}$ HEPES, $1 \mathrm{~mm}$ EDTA ( $\mathrm{pH}$ 8.0)). DNA was fragmented by passing the solution through a $21 \mathrm{~g}$ needle $3-4$ times. Protein concentration was determined using the Bio-Rad DC Protein Assay. Samples were mixed with $2 \times$ Laemmli lysis buffer $(1 \times=2.4 \mathrm{M}$ glycerol, $0.14 \mathrm{M}$ Tris, $\mathrm{pH} 6.8,0.21 \mathrm{M}$ sodium dodecylsulphate, $1.28 \mathrm{M}$ mercaptoethanol, $0.3 \mathrm{~mm}$ bromophenol blue). Protein $(50 \mu \mathrm{g})$ was added per lane on a $10 \%$ separation SDS-polyacrylamide gel (acrylamide:bis-acrylamide 20:1). Gels were run at $200 \mathrm{~V}$ in $25 \mathrm{~mm}$ Tris, $192 \mathrm{~mm}$ Glycine, $0.1 \%$ SDS and resolved 
proteins were transferred to nitrocellulose overnight at $4^{\circ} \mathrm{C} 22 \mathrm{~V}$ in $25 \mathrm{~mm}$ Tris, $192 \mathrm{~mm}$ Glycine, 20\% v v ${ }^{-1}$ methanol buffer. To block non-specific sites, filters were incubated with Blotto $(5 \%$ nonfat dry milk, $0.02 \%$ sodium azide, $0.01 \%$ Antifoam A in PBS) for $1 \mathrm{~h}$ at room temperature. Blots were probed with antiGlut1 polyclonal antibody by incubation at room temperature for $1 \mathrm{~h}$. This antibody was generated against the C-terminal 13 amino acids (gift from Dr. Mike Meckler) diluted 1:1000, or purchased from DAKO (Marshall et al, 1993). The membrane was washed with PBS and subsequently incubated with the secondary antibody horseradish peroxidase conjugated donkey anti-rabbit IgG (diluted $1: 500)$ for $1-2 \mathrm{~h}$. The membrane was rinsed in Blotto, and the amount of binding visualised by using enhanced chemiluminescence method (ECL, Amersham Pharmacia Biotech). Film exposure ranged from $10 \mathrm{~s}$ to $1 \mathrm{~min}$. The blots were stained with $0.5 \%$ Ponceau in $5 \%$ TCA to confirm uniform protein transfer prior to antibody reactions. Where indicated the membranes were stripped in $100 \mathrm{mM} \beta$-mercaptoethanol, $2 \%$ SDS, $62.5 \mathrm{mM}$ Tris$\mathrm{HCl} \mathrm{pH} 6.8$ at $55^{\circ} \mathrm{C}$ for $30 \mathrm{~min}$ and re-probed with anti-actin antibody (diluted 1:40 obtained from Calbiochem) for $1 \mathrm{~h}$ at room temperature. Secondary antibody incubation and development were performed as described.

\section{PARP Western blot analysis}

Cells were grown as above and lysed with buffer containing $62.5 \mathrm{~mm}$ Tris $\mathrm{pH} 6.8,8 \mathrm{~m}$ deionised urea, $10 \%$ glycerol, $2 \%$ SDS and protease inhibitor stock solutions (final concentration: $1 \mu \mathrm{g} \mathrm{ml}^{-1}$ Leupeptin, $1 \mu \mathrm{g} \mathrm{ml}^{-1}$ antipain, $1 \mu \mathrm{g} \mathrm{ml}^{-1}$ benzamidine, trypsin inhibitor $5 \mu \mathrm{g} \mathrm{ml}^{-1}, 1 \mu \mathrm{g} \mathrm{ml}^{-1}$ chymostatin, $1 \mu \mathrm{g} \mathrm{ml}^{-1}$ pepstatin A, $87 \mu \mathrm{g} \mathrm{ml}^{-1}$ PMSF). Samples were sonicated for $20 \mathrm{~s}$ to fragment the DNA. Samples containing $50 \mu \mathrm{g}$ of protein were heated to $65^{\circ} \mathrm{C}$ and size-separated protein on $7.5 \%$ gel. Protein was transferred to nitrocellulose as described above. After blocking non-specific binding sites with Blotto, filters were probed with anti-PARP antibody diluted 1:5000 (Biomol) for $2.5 \mathrm{~h}$ at room temperature. Filters were washed with PBS and subsequently incubated with the secondary antibody anti-mouse Ig conjugated to horseradish peroxidase diluted $1: 2000$ for $1 \mathrm{~h}$ at room temperature. Antibody binding was determined using ECL as described above. Positive controls were SkBr3 cells treated with $2 \mu \mathrm{M}$ staurosporine for $6 \mathrm{~h}$.

\section{Caspase-3 assay}

Caspase 3 activity was determined using ApoAlert Caspase-3 Assay Kit (Clontech). $2 \times 10^{6}$ cells were used for each time point. After the indicated treatments, cells were lysed by the addition of $50 \mu \mathrm{l}$ of the provided lysis buffer and incubation on ice for $10 \mathrm{~min}$. The non-soluble debris was removed by centrifugation at 14000 r.p.m. for $3 \mathrm{~min}$. Fifty microlitres of the supernatant was mixed with $50 \mu \mathrm{l}$ of the provided reaction buffer. Where indicated, $0.5-1 \mu \mathrm{l}$ of $1 \mathrm{mM}$ DEVD-Fmk inhibitor was preincubated with the indicated specimens at $37^{\circ} \mathrm{C}$ for $30 \mathrm{~min}$. Five microlitres of substrate $1 \mathrm{mM}$ DEVD-pNA was added to each sample and the reaction allowed to run at $37^{\circ} \mathrm{C}$ for $1 \mathrm{~h}$. Samples incubated without substrate served as the negative control. Absorbance was measured at $405 \mathrm{~nm}$ and using $655 \mathrm{~nm}$ as an internal reference.

\section{RESULTS}

\section{Effect of 2DG on cell growth, clonogenic survival, and} viability

Glucose-deprivation has been shown to cause apoptosis in breast cancer cell lines (Lee et al, 1997). To determine whether a similar result could be achieved using the non-metabolisable glucose analogue 2DG, which is known to inhibit glucose metabolism (Wick et al, 1957), four human breast cancer cell lines MCF-7, $\mathrm{SkBr3}$, BT549, and MDA/MB468 were grown in the presence of varying concentrations of 2DG. Representative growth curves from two of these cell lines are shown in Figure 2. 2DG was added to cells on day zero at concentrations ranging from $4-12 \mathrm{~mm}$. As seen in Figure 2A, growth of MDA/MB468 cells was completely inhibited by treatment with $8 \mathrm{mM}$ 2DG. Treatment with $4 \mathrm{~mm}$ 2DG resulted in approximately $30 \%$ inhibition of cell growth. Of the breast cancer cell lines tested, $\mathrm{SkBr} 3$ was the most sensitive to the growth inhibitory effects of 2DG. Cell growth was completely inhibited at $4 \mathrm{~mm} 2 \mathrm{DG}$ (Figure 2B). This represents a ratio of 2DG to glucose in the culture media of $1: 4.25$. This is consistent with previous cell culture studies in which a ratio of 1 part 2DG to 3 parts glucose inhibited glycolysis approximately 50\% (Laszlo et al, 1960). These experiments indicate that 2DG inhibits breast cancer cell growth which may be due to either growth arrest or cell death and that competition for essential sites of inhibition is in favour of 2DG.

It has previously been reported that normal cells undergo withdrawal from the cell cycle during nutrient or glucose deprivation rather than undergo cell death (Shim et al, 1998). To determine whether treatment with 2DG resulted in cell death or withdrawal from the cell cycle, clonogenic survival and MTT assays were performed. For the clonogenic survival experiments, SkBr3 cells were treated with 2DG for $4 \mathrm{~h}$, re-cultured at low density in normal media, and colony formation determined at 14 days. As seen in Figure 3, there is a dose dependent decrease in clonogenic survival with 2DG treatment. Treatment with $4 \mathrm{~mm} 2 \mathrm{DG}$ for $4 \mathrm{~h}$ results in $50 \%$ decrease in cell survival at 14 days compared to non-treated control cells. These results indicate that 2DG treatment causes cell death as reflected by decreased clonogenicity rather than withdrawal from the cell cycle.

MTT is reduced by viable cells to a coloured formazan product and has been previously found to correlate with clonogenic survival and has been used for chemosensitivity testing (Carmichael et al, 1987). To determine whether reduction of MTT paralleled clonogenic survival, breast cancer cell lines were treated with varying concentrations of 2DG and spectrophotometric conversion of MTT measured. As seen in Figure 4, 2DG treatment of three breast cancer cell lines for $4 \mathrm{~h}$ resulted in a dose dependent decrease in absorption at $550 \mathrm{~nm}$ indicting decreased reduction of MTT to its formazan product. Treatment with $1 \mathrm{~mm}$ 2DG resulted in an approximately $40 \%$ decrease in the reduction of MTT by $\mathrm{SkBr} 3$ cells, approximately $25 \%$ decrease by MCF7 cells, and no change by the MDA/MB468 cell line. When $\mathrm{SkBr} 3$ cells treated with $3 \mathrm{mM} 2 \mathrm{DG}$ for $24 \mathrm{~h}$ and allowed to recover for $6 \mathrm{~h}$ a slight increase in MTT reduction is observed ( $50 \%$ vs $61 \%$, data not shown). As observed in the cell growth experiments, the $\mathrm{SkBr} 3$ cell line appeared to be more sensitive to the effects of 2DG than MCF-7 and MBA/MB468 breast cancer cell lines in this assay. In addition, these results parallel the results of the clonogenic survival assay and indicate that the MTT conversion correlates with cell survival with 2DG treated cells.

\section{Caspase 3 activity and PARP cleavage with 2DG treatment}

Clonogenic survival and MTT assays encompass all types of cell death including necrosis and apoptosis. Apoptotic cell death is an active death process and can be inferred by measuring the activation of caspases and the cleavage of key enzymes. To determine whether the cell death caused by 2DG involves apoptosis, cells were examined for caspase 3 activity and PARP cleavage. Caspase 3 is an essential protease activated during apoptotic cascade (Gross et al, 1999). Caspase 3 activity was measured in SkBr3 cells after treatment with 2DG using a spectrophotometric assay based on the cleavage of DEVD-pNA, a substrate for caspase 3. As seen in Figure 
A

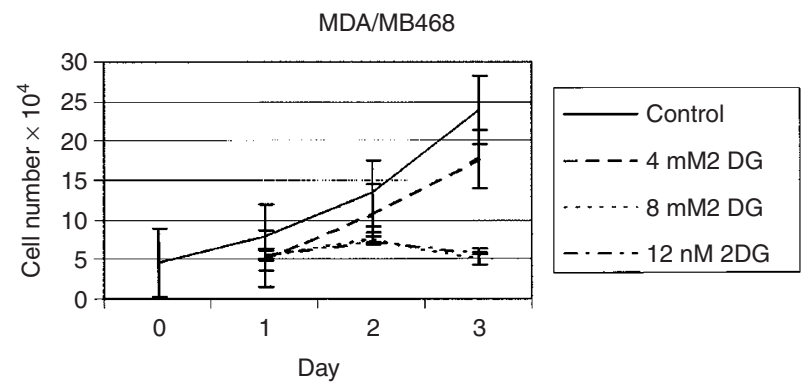

B

SKBR3

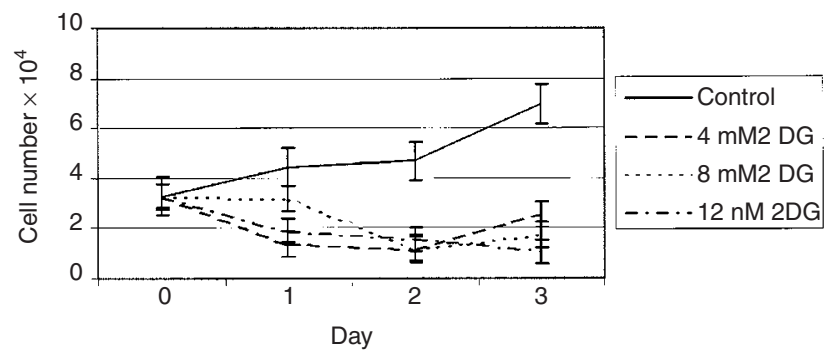

Figure 2 Effect of 2-DG on growth of breast cancer cell lines. $\mathrm{SkBr} 3$ and MDA/MB468 breast cancer cell lines were grown in the absence or presence of various concentrations of 2DG. 2DG was added on day zero and the media was not changed during the duration of the experiment. Cell number was determined daily. Each point represents triplicate cultures.

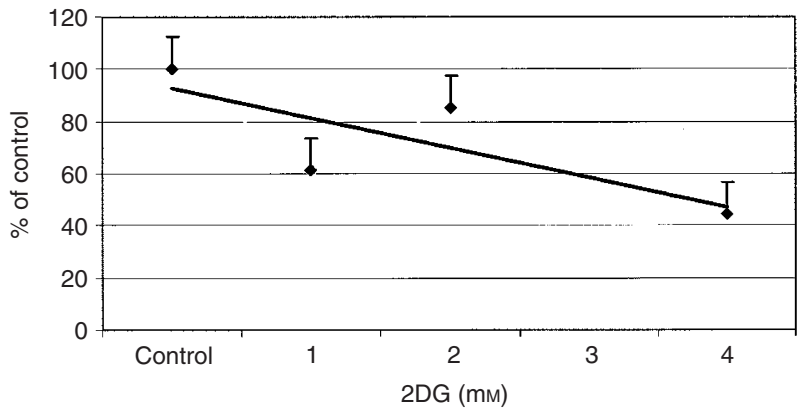

Figure 3 Clonogenic survival after 2DG treatment. $\mathrm{SkBr} 3$ cells were treated with varying concentrations of 2DG for $4 \mathrm{~h}$ and replated at low density. Colonies were counted 14 days after plating and those containing 25 cells or greater were scored as positive. Each point represents triplicate cultures.

5 , treatment of $\mathrm{SkBr} 3$ cells with $2 \mathrm{DG}$ results in a time dependent increase of caspase 3 activity. Caspase 3 activity increased by three-fold over control cells after treatment with $16 \mathrm{~mm} 2 \mathrm{DG}$ for $6 \mathrm{~h}$. This activity was inhibited by pre-incubation with the caspase 3 inhibitor DEVD-FMK.

Poly (ADP-ribose) polymerase (PARP) is involved in DNA cleavage during apoptosis. During apoptosis the $116 \mathrm{kDa}$ PARP enzyme is cleaved by caspases to an $89 \mathrm{kDa}$ form which is no longer stimulated by nicked DNA (Shah et al, 1995). PARP cleavage was determined after treatment of $\mathrm{SkBr} 3$ cells with 2DG. In this experiment, $\mathrm{SkBr} 3$ cells were treated with either $12 \mathrm{mM}$ 2DG for $6 \mathrm{~h}$ or $2 \mu \mathrm{M}$ staurosporine. Staurosporine has previously been shown to be a potent inducer of apoptosis and was used as a positive control (Tafani et al, 2001). Cleavage of PARP was determined

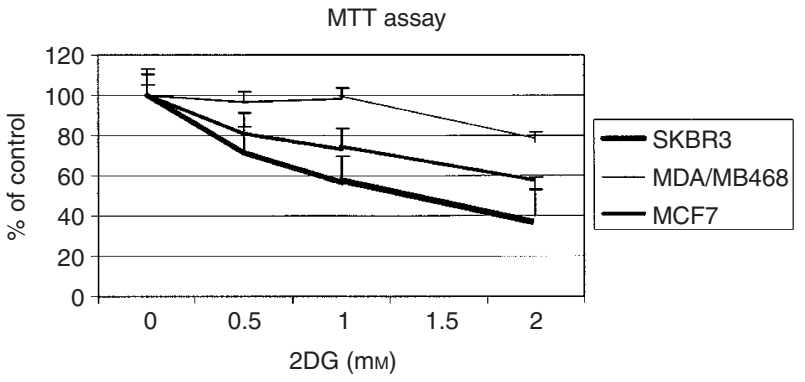

Figure 4 MTT conversion after 2DG treatment. SkBr3, MDA/MB468, and MCF7 cells were incubated with the indicated concentrations of 2DG for $4 \mathrm{~h}$. MTT was added the amount of reduced formazan product determined spectrophotometrically. Results are expressed as per cent of control non-treated cells.

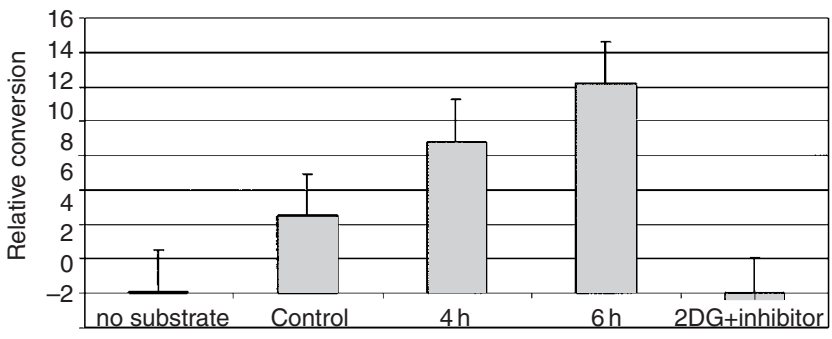

Figure 5 Caspase 3 activation in $\mathrm{SkBr} 3$ cells treated with 2DG. $\mathrm{SkBr} 3$ cells were treated with $16 \mathrm{~mm}$ 2DG for the 4 or $6 \mathrm{~h}$. Cells were harvested and caspase 3 activity measured using a spectrophotometric assay according to the manufacturer's instructions. The caspase 3 inhibitor DEVD-FMK was added 30 min prior to the addition of substrate in cells which had been incubated with $16 \mathrm{mM}$ 2DG for $6 \mathrm{~h}$. Each point represents the average of triplicate cultures. Control cells were incubated for $6 \mathrm{~h}$ in the presence of media only.

by Western blot analysis using a monoclonal antibody to PARP. As seen in Figure 6, control cells had undetectable amounts of the PARP cleavage product (lane 1). In contrast, $\mathrm{SkBr} 3$ cells with 2DG or staurosporine resulted in the appearance of the $89 \mathrm{kDa}$ PARP cleavage product. Cells treated with 2DG had approximately $20 \%$ cleavage of the protein (lane 3 ). In addition, 2DG treatment of $\mathrm{SkBr} 3$ cells leads to DNA cleavage (unpublished data). These results together with the results of the caspase 3 activity experiments indicate that cell death caused by $2 \mathrm{DG}$ in $\mathrm{SkBr} 3$ cells occurs in part through apoptosis.

\section{Glut1 transporter expression and glucose uptake with 2DG treatment}

The Glut1 glucose transporter is an integral membrane glycoprotein and is responsible for constitutive glucose uptake in breast cancer cells. Glut1 protein expression is increased in cancer cells and has been reported to increase during cellular stress and upon glucose deprivation (Kitzman et al, 1993; Blackburn et al, 1999). Glutl contains an N-glycosylation consensus sequence in the first exofacial loop. As a result of heterogeneous glycosylation at this site, the transporter migrates as a broad band on SDS-PAGE gels (Marshall et al, 1993). Previous studies have demonstrated that glucose deprivation alters the glycosylation pattern of Glut1 resulting in a lower molecular weight species of the transporter which migrates as an approximately $37 \mathrm{kDa}$ protein (Kitzman et al, 1993). This transporter species undergoes appropriate trafficking to the plasma membrane (MacMahon and Frost, 1995; Macmahon et al, 2000). To determine the effect of 2DG on Glut1 transporter 


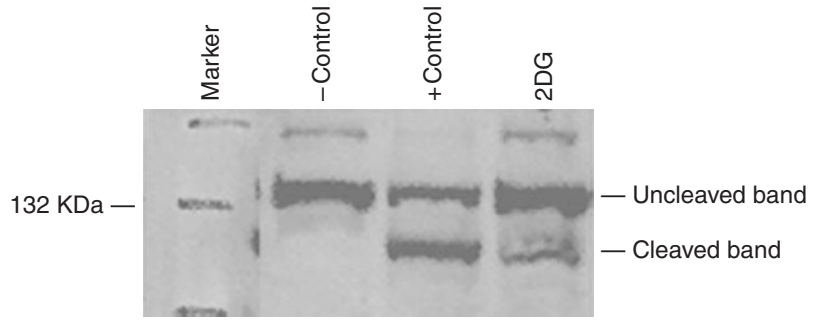

Figure 6 PARP activation by $\mathrm{SkBr} 3$ cells treated with 2-DG. Cells were treated for $6 \mathrm{~h}$ with $12 \mathrm{mM} 2 \mathrm{DG}$ or $2 \mu \mathrm{M}$ staurosporine (+control). Western blot analysis was performed using a monoclonal antibody to PARP. Normal (uncleaved) and the PARP cleavage product are indicated.

levels and glycosylation pattern, $\mathrm{SkBr} 3$ cells were harvested after treatment with $8 \mathrm{mM} 2 \mathrm{DG}$ for 48 or $72 \mathrm{~h}$, and Glutl expression determined by Western blot analysis using a rabbit polyclonal antibody prepared to a 13 amino acid C-terminal fragment of Glut1 (Marshall et al, 1993). Fully glycosylated Glut1 migrates as a broad band at approximately $47 \mathrm{kDa}$. This can be seen in Figure 7, lanes 1 and 3. Control lysates demonstrating high Glut1 transporter expression are protein isolated from human placenta (lane 1) and plasma membranes isolated from Xenopus oocytes injected with a human Glutl expression vector (lane 3) (Carayannopoulos et al, 2000). Lane 2 represents protein isolated from sham injected Xenopus oocytes. SkBr3 cells were incubated with either 0 or $8 \mathrm{~mm}$ $2 \mathrm{DG}$ for 48 or $72 \mathrm{~h}$ and protein extracts prepared. As seen in lanes 5 and 7, 2DG treatment results in the appearance of a lower molecular weight glycoform of Glut 1 is seen which migrates as a $37-\mathrm{kDa}$ protein. This is in contrast to protein isolated from cells which were not incubated with 2DG which had very low levels of Glut 1 protein (Figure 7, lanes 4 and 6). In addition, there is greater intensity of the bands reflecting higher levels of Glut1 protein. The same blot probed with anti-actin antibody demonstrated similar amounts of actin in each sample. This experiment indicates that 2DG treatment of $\mathrm{SkBr} 3$ cells results in increased amounts of Glut 1 protein as well as a lower molecular weight protein which is likely the result of an altered glycosylation pattern.

To determine whether glucose uptake increased or decreased with 2DG treatment, glucose uptake was measured in $\mathrm{SkBr} 3$ cells after treatment with $8 \mathrm{mM} 2 \mathrm{DG}$ for $4 \mathrm{~h}$ using the non-metabolisable glucose analogue 3-O-methyl-glucose (3-O-MG). 3-O-MG is not appreciably phosphorylated by cells and reaches equilibrium between extracellular and intracellular spaces. Specific uptake of 3-O-MG by the Glut1 transporter is inhibited by cytochalasin B (Hamrahian et al, 1999). As shown in Figure 8, 3-O-MG uptake is three-fold higher in 2DG treated cells than control cells. Increased uptake of 3-O-MG observed with 2DG treatment was inhibited by pretreatment with cytochalasin $\mathrm{B}$. This data indicates that 2DG treatment of breast cancer cells results in increased glucose uptake which may be due to higher levels of Glut1 protein.

\section{DISCUSSION}

Breast cancers exhibit an increased rate of glucose uptake and express high levels of glucose transporter protein (Wahl et al, 1991; Brown and Wahl, 1993; Younes et al, 1995). Recently, glucose-deprivation has been reported to cause apoptosis in breast cancer cells (Lee et al, 1997). These observations lead us to hypothesise that interference with glucose metabolism by nonmetabolisable glucose analogues would lead to apoptosis in breast cancer cells. Previous studies have demonstrated that interference with glycolysis by the non-metabolisable glucose analogue 2DG can cause cell killing through interference with glycolysis (Kaplan et al, 1990a; Nomura et al, 1999; Ko et al, 2001). The experimental
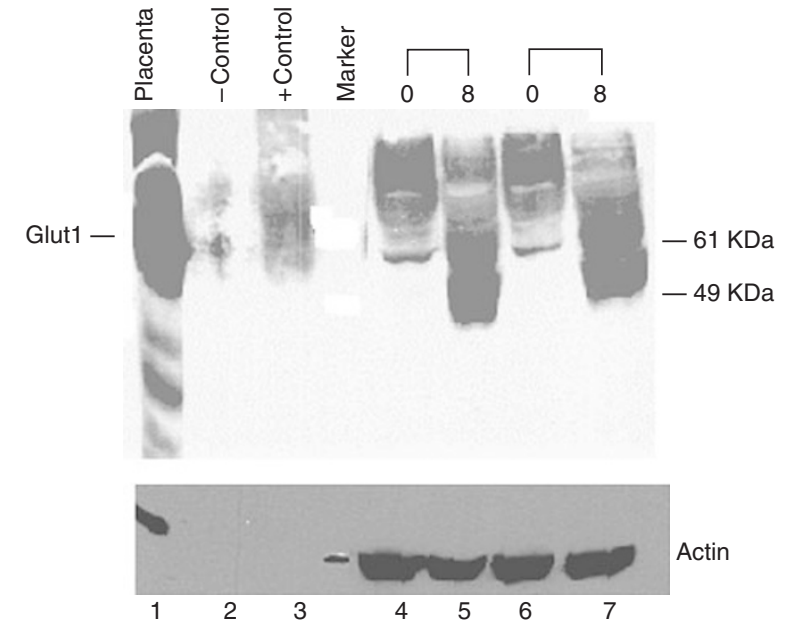

Figure 7 Glut-I transporter protein levels in breast cancer cells lines treated with 2-DG. $\mathrm{SkBr} 3$ breast cancer cells were treated with 2DG for 48 or 72 h with 8 mM 2DG (8) or without 2DG (0). Protein was isolated, size separated on a 10\% polyacrylamide gel. A Western blot was performed using a polyclonal anti-Glut-I antibody. Positive controls are protein isolated from human placenta and membranes isolated from Glut injected Xenopus oocytes (+control). Sham injected oocytes were used as a negative control (-control). Glutl protein is indicated. Molecular weight markers are labelled. The protein blot was reacted with anti-actin antibody after removal of the Glut I antibody (lower panel)

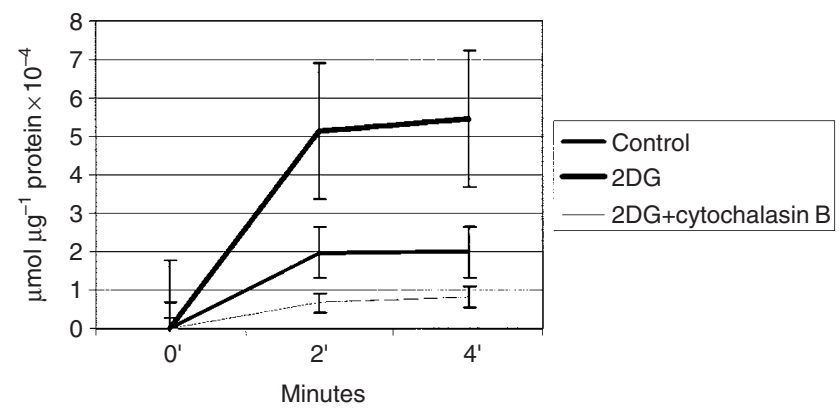

Figure 8 Glucose uptake by $\mathrm{SkBr} 3$ cells treated with 2-DG. SkBr3 cells were treated with $8 \mathrm{~mm} 2-\mathrm{DG}$ and $\left[{ }^{14} \mathrm{C}\right] 3-\mathrm{O}-$ methyl-glucose uptake measured. Cytochalasin B (50 $\mu \mathrm{M})$ was added simultaneously with the radioactive glucose.

results presented here extend previous observations and confirm our hypothesis by demonstrating that glucose-deprivation induced by $2 \mathrm{DG}$ leads to cessation of cell growth, decreases clonogenicity, and causes apoptosis in breast cancer cell lines. Furthermore, breast cancer cells treated with 2DG express higher levels of Glut transporter and demonstrate increased glucose uptake as a result of oxidative stress. Therefore, 2DG appears to be an effective agent for causing breast cancer cell death due to the initial response of accelerated glucose uptake by the stressed cells.

It has been hypothesised that increased glucose uptake may represent an important regulatory point in maintaining the growth and synthetic activity of malignant cells and suppression of apoptosis (Greiner et al, 1994; Kan et al, 1994). For example, c-Myc transformed rat fibroblasts up-regulate glucose transport and glycolytic gene expression through trans-activation (Osthus et al, 2000). These cells will undergo apoptosis upon withdrawal of glucose (Shim et al, 1998). In normal cells, growth is regulated by external growth signals and nutrient support (Rathmell et al, 2000; Vander Heiden et al, 2001). Cancer cells, in contrast, have lost responsive- 
ness to most external growth signalling and as a consequence, nutrient supply in the form of glucose likely plays a unique role in maintaining cancer cell viability. Thus, normal and transformed cells respond to nutrient depletion or glucose-deprivation in opposing manners. Whereas normal cells compensate by increased glucose transporter expression or modification, transformed cells are stressed by glucose-deprivation leading to the expression of an array of stress related genes, which is subsequently followed by cell death. In many normal cell types, glucose deprivation results in an increase in the maximum velocity of glucose transport (Kitzman et al, 1993). This has been attributed to one of several mechanisms; translocation of transporter from an intracellular compartment to the plasma membrane (Haspel et al, 1991), changes in the glycosylation pattern of the Glutl transporter with decreased turnover of the protein (Macmahon and Frost, 1995), or by increased synthesis of m RNA and protein (Reed et al, 1990; von der Crone et al, 2000). For example, pre-adipocyte cell lines respond to glucose starvation by increasing transporter expression reflected in elevated levels of Glut1 transporter mRNA and protein (Reed et al, 1990). 3T3 cells respond to glucose-deprivation by conversion of the native Glutl transporter to an incompletely glycosylated form, while increasing basal transport 4.5-fold (Reed et al, 1990; Macmahon and Frost, 1995). Prolonged glucose deprivation, in non-transformed cell lines, causes cell-cycle arrest in $\mathrm{G}_{0} / \mathrm{G}_{1}$, which is reversible (Shim et al, 1998). In contrast, many transformed cell lines respond to glucose deprivation initially by expression of an array of stress related genes and subsequently undergoing apoptosis (Lee and Corry, 1998). For example, early in glucose deprivation, MCF7/Adr cells have increased levels of Lyn and c-Jun kinases as well as increased expression of bFGF and c-Myc mRNAs (Galoforo et al, 1996; Gupta et al, 1997; Liu et al, 1997; Lee et al, 1998). These results support the hypothesis that cancer cells are uniquely sensitive to glucose-deprivation and glucose-deprivation results in cellular stress and subsequent cytotoxicity.

Glucose-deprivation can be mimicked with glucose antagonists. Glucose analogues have been found to profoundly inhibit glucose metabolism in cancer cells in vitro as well as in vivo (Ball et al, 1957; Laszlo et al, 1960). Of the many glucose analogues, which have been investigated, 2DG appears to be the most effective in inhibiting glycolysis (Laszlo et al, 1958). 2DG is a structural analogue of glucose differing at the second carbon atom by the substitution of hydrogen for a hydroxyl group and appears to selectively accumulate in cancer cells (Figure 1). 2DG undergoes facilitated diffusion into cells via glucose transporters. Once intracellular, 2DG is phosphorylated by hexokinase to 2-deoxy-Dglucose-6-phosphate (2-DG-6-P). 2-DG-6-P is not a substrate for glucose-6-phosphate dehydrogenase or phosphohexoisomerase (Wick et al, 1957). Therefore, once formed, 2-DG-6-P is not further metabolised and will accumulate in the cell until de-phosphorylated by phosphorylase (Gallagher et al, 1978; Kern and Norton, 1987; Nelson et al, 1996). In malignant cells, specific accumulation of $2 \mathrm{DG}$ is attributed to several mechanisms; increased glucose transporter expression resulting in increased uptake (Waki et al, 1998), increased hexokinase activity or phosphorylating activity resulting in trapping (Kaplan et al, 1990a; Aloj et al, 1999), and low phosphorylase activity resulting in accumulation (Kern and Norton, 1987; Nelson et al, 1996). Inhibition of glycolysis by 2DG is thought to occur by inhibition of key glycolytic enzymes such as phosphohexoisomerase (Horton et al, 1982) as well as depletion of high energy compounds. 2-DG-6-P may act as a potent $P_{i}$ trap resulting in depletion of intracellular stores. Low $\mathrm{P}_{\mathrm{i}}$ rapidly leads to dephosphorylation of ATP with a concomitant increase in AMP. High AMP and low $\mathrm{P}_{\mathrm{i}}$ stimulates AMP deaminase, which converts AMP to inosine and leads to a decrease in the total adenine pool. The low $\mathrm{P}_{\mathrm{i}}$ and ATP makes hexokinase far more susceptible to inhibition by G-6-P which may occur by feedback inhibition and/or allosteric inhibition (Ardehali et al, 1996, 1999).

Hexokinase may be the key regulator in 2DG-induced apoptosis. Hexokinase is the first enzyme of the glycolytic reaction Glucose+MgATP $->$ Glucose-6- $\mathrm{PO}_{4}+\mathrm{MgADP}$ which commits glucose to undergo metabolism. The phosphorylation of glucose by hexokinase ensures glucose entry into cells via facilitated diffusion along a downhill concentration gradient. Four isoenzymes of hexokinase are found in mammalian tissues and are subject to allosteric inhibition by the product Glucose-6- $\mathrm{PO}_{4}$ (Wilson, 1997). Type II hexokinase, the isoform over-expressed in transformed cells, has the highest $\mathrm{Km}$ for glucose (Parry and Pedersen, 1983; Rempel et al, 1996). Markedly elevated levels of hexokinase II have been described in many malignant cell lines and unlike normal tissue, $50-80 \%$ of the enzyme is bound to the mitochondrial fraction, where it is thought to have preferential access to intramitochondrially generated ATP and be more resistant to Glucose-6- $\mathrm{PO}_{4}$ inhibition (Arora and Pedersen, 1988; Arora et al, 1992). In addition, hexokinase forms one component of the proposed permeability transition pore, which is involved in mitochondria depolarisation following apoptotic signals (Gross et al, 1999). Recently published data supports a role of hexokinase activity in the prevention of apoptosis mediated by Akt (Gottlob et al, 2001). Thus, it is possible that hexokinase expressed in cancer cells may be uniquely sensitive to 2DG which may have a direct effect on the apoptotic signal pathway through its role as a member of the permeability transition pore complex.

A related mechanism for the triggering of apoptosis by glucosedeprivation or 2DG may be induction of stress-related signals caused by an imbalance in the energy state of the cell subsequent to ATP depletion. One method to avoid apoptosis would be to maintain a favourable energy balance. Should the latter fall below a certain crucial point, the pre-existing program for apoptosis would be executed through the expression of stress related genes (Kan et al, 1994). Previous studies have shown that 2DG inhibits the rate of glucose usage and glycolysis cancer cell lines by 15$40 \%$ resulting in reduced ATP levels by nearly $40 \%$ tested cell lines (Kaplan et al, 1991; Dwarkanath et al, 2001). Glucose-deprivation results in activation of the MAP kinase pathway as a result of oxidative stress (Lee et al, 1998; Blackburn et al, 1999; Spitz et $a l, 2000)$. This pathway is suppressed by over-expression of $\mathrm{Bcl}-2$ which is reported to suppress apoptogenic activity involving mitochondria through an antioxidant pathway (Hockenbery et al, 1993; Zhong et al, 1993; Lee et al, 1997; Lee and Corry, 1998; Shim et al, 1998). This would support a role for alteration in the energy balance of the cell in induction of apoptosis with glucose deprivation or 2DG treatment.

In this report we present data demonstrating that 2DG treatment of breast cancer cells leads to cell death which occurs in part by apoptosis. Four breast cancer cell lines were tested which demonstrated varying sensitivity to the cytotoxic effect of 2DG. $\mathrm{SkBr} 3$ cells were the most sensitive to the effects of 2DG demonstrating a $50 \%$ decrease in clonogenicity at a concentration of $4 \mathrm{mM}$ 2DG. Variability to 2DG induced cytotoxicity has been previously reported and related to a multi-drug resistant phenotype (Kaplan et al, 1991). However, variability of 2DG induced cytotoxicity may be related to the complexity of uptake and processing or to the levels of pro-apoptotic or anti-apoptotic proteins (Amundson et al, 2000). We have further demonstrated that 2DG causes cell death rather than withdrawal from the cell cycle using clonogenic survival. The mechanism of cell death induced by 2DG appears to be by apoptosis as demonstrated by capase 3 and PARP activation. Slightly higher concentrations of $2 \mathrm{DG}$ were required to observe a significant amount of apoptosis compared with clonogenic survival in SkBr3 cells. This would be consistent with 2DG causing cell death by methods other than apoptosis exclusively such as necrosis (Sperandio et al, 2000; Tannock and Lee, 2001). 
Glucose deprivation results in increased glucose uptake and Glut1 transporter expression (Fisher and Frost, 1996). Under these conditions, an incompletely glycosylated form of Glut1 is synthesised which migrates as a $37 \mathrm{kDa}$ protein (Reed et al, 1990; Kitzman et al, 1993; Macmahon et al, 2000). Our experiments demonstrate a similar response upon treatment of breast cancer cells with 2DG. 2DG treatment of breast cancer cells resulted in an increased glucose uptake as well as expression of higher levels of Glut1 glucose transporter. A lower molecular weight Glut1 protein was detected which likely represents an incomplete glycosylated form. From our results, we hypothesise that breast cancer cells treated with 2DG accelerate their own demise as a result of increased glucose transport as an initial response to 2DG.

Two properties of 2-DG, inhibition of glycolysis and preferential accumulation in cancer cells have formed the basis for further investigating the mechanism of $2 \mathrm{DG}$ for use as an anti-tumour agent. We speculate that cancer cells initially treated with 2DG exhibit a stress response due to a depletion of intracellular energy. The stress response results in increased levels of glucose transporter expression and increased glucose uptake, which allows more 2DG to enter the cell. As a consequence of high intracellular concentrations 2DG, hexokinase and hexose phosphate isomerase are inhibited, energy stores such as ATP are further depleted,

\section{REFERENCES}

Aloj L, Caraco C, Jagoda E, Eckelman W, Neumann R (1999) Glut-1 and hexokinase expression: relationship with 2-fluoro-2-deoxy-D-glucose uptake in A431 and T47D cells in culture. Cancer Res 59: 4709-4714

Amundson S, Myers T, Scudiero D, Kitada S, Reed J, Fornace A (2000) An informatics approach identifying markers of chemosensitivity in human cancer cell lines. Cancer Res 60: 6101-6110

Ardehali H, Printz R, Whitesell R, May J, Granner D (1999) Functional interaction between the $\mathrm{N}$ - and C-terminal halves of human hexokinase II. $J$ Biol Chem 274: $15986-15989$

Ardehali H, Yano H, Printz R, Koch S, Whitesell R, May J, Granner D (1996) Functional organization of mammalian hexokinase II. J Biol Chem 271: $1849-1852$

Arora K, Parry D, Pedersen P (1992) Hexokinase receptors: preferential enzyme binding in normal cells to non-mitochondrial sites and in transformed cells to mitochondrial sites. J Bioenergetics Biomembranes 24: $47-53$

Arora K, Pedersen P (1988) Functional significance of mitochondrial bound hexokinase in tumor cell metabolism. J Biol Chem 263: $17422-17428$

Ball H, Wick A, Sanders C (1957) Influence of glucose anti-metabolites on the Walker tumor. Cancer Res 17: 235-239

Bentley J, Walker I, McIntosh E, Whetton A, Owen-Lynch P, Baldwin S (2001) Glucose transport regulation by p210 Bcr-Abl in a chronic myeloid leukemia model. Br J Haematol 112: 212-215

Birnbaum M, Haspel H, Rosen O (1987) Transformation of rat fibroblasts by FSV rapidly increases glucose transporter gene transcription. Science 235: $1495-1498$

Blackburn R, Spitz D, Liu X, Galoforo S, Sim J, Ridnour L, Chen J, Davis B, Corry P, Lee Y (1999) Metabolic oxidative stress activates signal transduction and gene expression during glucose deprivation in human tumor cells. Free Radic Biol Med 26: 419-430

Brown R, Wahl R (1993) Over-expression of Glutl glucose transporter in human breast cancer: an immunohistochemistry study. Cancer 15: 2979-2985

Carayannopoulos M, Chi M, Cui Y, Pingsterhaus J, McKnight R, Mueckler M, Devaskar S, Moley K (2000) GLUT8 is a glucose transporter responsible for insulin-stimulated glucose uptake in the blastocyst. Proc Natl Acad Sci USA 97: $7313-7318$

Carmichael J, DeGraff W, Gadzar A, Minna J, Mitchell J (1987) Evaluation of a tetrazolium-based semiautomated colorimetric assay: assessment of chemosensitivity testing. Cancer Res 47: 936-942

Dwarkanath B, Zolzer F, Chandana S, Bauch T, Adhikari J, Muller W, Streffer C, Jain V (2001) Heterogeneity in 2-deoxy-D-glucose-induced modifications in energetics and radiation responses of human tumor cell lines. Int J Radiat Oncol Biol Phys 50: 1051-1061 and the cell activates the cell death pathway. Cancer cells are dependent on glycolysis for energy production and appear to be uniquely sensitive to glucose-deprivation and the effects of 2DG (Kaplan et al, 1991). The concentrations of 2DG which we observe to be cytotoxic to breast cancer cells in vitro are achievable in vivo (Mohanti et al, 1996). In several animal models of experimental malignancies tumour growth was inhibited with 2DG treatment (Laszlo et al, 1960; Kern and Norton, 1987; Ko et al, 2001). Clinical experience with 2DG has been favorable but limited (Landau et al, 1958; Mohanti et al, 1996). We think interference with glucose metabolism by tumour specific glucose analogues such as 2DG may serve as an effective agent or sensitiser to other therapeutic modalities especially in multidrug resistant cells.

\section{ACKNOWLEDGEMENTS}

The authors would like to thank Drs Jeffrey Moley, Kelle Moley, and John Phay for helpful discussions, Dr Mary Carayannopoulis for providing protein from Glut1 injected oocytes and Dr Mike Mueckler for providing Glut1 antibody.

Fisher M, Frost S (1996) Translocation of Glutl does not account for elevated glucose transport in glucose-deprived 3T3-L1 adipocytes. J Biol Chem 271: $11806-11809$

Flier J, Mueckler M, Usher P, Lodish H (1987) Elevated levels of glucose transport and transporter mRNA are induced by ras or src oncogenes. Science 235: $1492-1495$

Gallagher B, Fowler J, Gutterson N, MacGregor R, Wan C, Wolf A (1978) Metabolic trapping as a principle of radiopharmaceutical design: some factors responsible for the biodistribution of $\left[{ }^{18} \mathrm{~F}\right]$ 2-deoxy-2-fluoro-Dglucose. J Nuclear Med 19: 1154-1161

Galoforo S, Berns C, Erdos G, Corry P, Lee Y (1996) Hypoglycemia-induced AP-1 transcription factor and basic fibroblast growth factor gene expression in multidrug resistant breast carcinoma MCF-7/ADR. Mol Cell Biochem 155: $163-171$

Gottlob K, Majewski N, Kennedy S, Kandel E, Robey R, Hay N (2001) Inhibition of early apoptotic events at Akt/PKB is dependent on the first committed step of glycolysis and mitochondrial hexokinase. Genes Dev 15: $1406-1418$

Greiner E, Guppy M, Brand K (1994) Glucose is essential for proliferation and the glycolytic enzyme induction that provokes a transition to glycolytic energy production. J Biol Chem 269: 31482-31490

Gross A, McDonnell J, Korsmeyer S (1999) BCL-2 family members and the mitochondria in apoptosis. Genes Dev 13: 1899-1911

Gupta A, Lee Y, Galoforo S, Berns C, Martinez A, Corry P, Wu X, Guan K (1997) Differential effect of glucose deprivation on MAPK activation in drug sensitive human breast carcinoma MCF-7 and multidrug resistant MCF-7/ADR cells. Mol Cell Biochem 170: 23-30

Hamrahian A, Zhang J, Elkhairi F, Prasad R, Ismail-Beigi F (1999) Activation of Glutl glucose transporter in response to inhibition of oxidative phosphorylation. Arch Biochem Biophys 368: 375-379

Haspel H, Mynarcik D, Oritz P, Honkanen R, Rosenfeld M (1991) Glucose deprivation induces the selective accumulation of hexose transporter Glut1 in the plasma membrane of normal rat kidneys. Mol Endocrinol 5: $61-72$

Hockenbery D, Oltvai Z, Yin X, Milliman C, Korsmeyer S (1993) Bcl-2 functions in an antioxidant pathway to prevent apoptosis. Cell 75: $241-251$

Horton R, Meldrum B, Bachelard H (1982) Enzymatic and cerebral metabolic effects of 2-deoxy-D-glucose. J Neurochem 21: 507-520

Jain V, Kalia V, Sharma R, Maharajan V, Menon M (1985) Effects of 2-deoxyD-glucose on glycolysis, proliferation kinetics and radiation response of human cancer cells. Int J Radiat Oncol Biol Phys 11: 943-950

Kan O, Baldwin S, Whetton A (1994) Apoptosis is regulated by the rate of glucose transport in an interleukin 3 dependent cell line. J Exp Med 180: $917-923$ 
Kaplan O, Jaroszewski J, Clarke R, Fairchild C, Schoenlein P, Goldenberg S, Gottesman M, Cohen J (1991) The multidrug resistance phenotype: 31P nuclear magnetic resonance characterization and 2-deoxyglucose toxicity. Cancer Res 51: 1638 - 1644

Kaplan O, Lyon R, Faustino P, Straka E, Cohen J (1990a) Effects of 2-deoxyglucose on drug-sensitive and drug-resistant human breast cancer cells: toxicity and magnetic resonance spectroscopy of metabolism. Cancer Res 50: $544-551$

Kaplan O, van Zijl P, Cohen J (1990b) Information from combined 1H and 31P NMR studies of cell extracts: differences in metabolism between drug sensitive and drug resistant MCF-7 human breast cancer cells. Biochem Biophys Res Commun 169: 383-390

Kern K, Norton J (1987) Inhibition of established rat fibrosarcoma growth by the glucose antagonist 2-deoxy-D-glucose. Surgery 102: 380-385

Kitzman H, McMahon R, Williams M, Frost S (1993) Effect of glucose deprivation on Glut1 expression in 3T3-L1 adipocytes. J Biol Chem 268: 1320 1325

Ko Y, Pedersen P, Geschwind J (2001) Glucose catabolism in the rabbit VX2 tumor model for liver cancer: characterization and targeting hexokinase. Cancer Lett 173: 83-91

Landau B, Laszlo J, Stengle J, Burk D (1958) Certain metabolic and pharmacologic effects in cancer patients given an infusion of 2-deoxy-D-glucose. $J$ Natl Cancer Inst 21: 485-494

Laszlo J, Humphreys S, Goldin A (1960) Effects of glucose analogues (2deoxy-D-glucose, 2-deoxy-D-galactose) on experimental tumors. J Natl Cancer Inst 24: 267-280

Laszlo J, Landau B, Wight K, Burk D (1958) The effect of glucose analogues on the metabolism of human leukemia cells. J Natl Cancer Inst 21: 475 483

Lee Y, Corry P (1998) Metabolic oxidative stress-induced HSP70 gene expression is mediated through SAPK pathway. J Biol Chem 273: 29857-29863

Lee Y, Galoforo S, Berns C, Chen J, Davis B, Sim J, Corry P, Spitz D (1998) Glucose deprivation-induced cytotoxicity and alterations in mitogen-activated protein kinase activation are mediated by oxidative stress in multidrug resistant human breast carcinoma cells. J Biol Chem 273: 5294-5299

Lee Y, Galoforo S, Berns C, Tong W, Kim H, Corry P (1997) Glucose deprivation-induced cytotoxicity in drug resistant human breast carcinoma MCF7/ADR cells: role of c-myc and bcl-2 in apoptotic cell death. J Cell Sci 110: $681-686$

Liu X, Gupta A, Corry P, Lee Y (1997) Hypo-glycemia-induced c-Jun phosphorylation is mediated by c-Jun $\mathrm{N}$-terminal kinase 1 and Lyn kinase in drug-resistant human breast carcinoma MCF-7/ADR cells. J Biol Chem 272: $11690-11693$

MacMahon R, Frost S (1995) Nutrient control of Glutl processing and turnover in 3T3-L1 adipocytes. J Biol Chem 270: 12094-12099

MacMahon R, Hwang J, Frost S (2000) Glucose deprivation does not affect Glut1 targeting in 3T3-L1 adipocytes. Biochem Biophys Res Commun 273: $859-864$

Marshall B, Ren J, Johnson D, Gibbs E, Lillquist J, Soeller W, Holloszy J, Mueckler M (1993) Germline manipulation of glucose homeostasis via alteration in glucose transporter levels in skeletal muscle. J Biol Chem 268: $18442-18445$

Mohanti B, Rath G, Anantha N, Kannan V, Das B, Chandramouli B, Banerjee A, Das S, Jena A, Ravichandran R, Sahi U, Kumar R, Kalia V, Dwarkanath B, Jain V (1996) Improving cancer radiotherapy with 2-deoxy-D-glucose: phase I/II trials on cerebral gliomas. Int J Radiat Oncol Biol Phys 35: 103 111

Nelson C, Wang J, Leav I, Crane P (1996) The interaction among glucose transport, hexokinase, and glucose-6-phosphatase with respect to ${ }^{3} \mathrm{H}-2$ deoxyglucose in murine tumor models. Nuclear Med Biol 23: 533-541

Nomura K, Imai H, Koumura T, Arai M, Nakagawa Y (1999) Mitochondrial phospholipid hydroperoxide glutathione peroxidase suppresses apoptosis mediated by a mitochondrial death pathway. J Biol Chem 274: $29294-$ 29302

Osthus R, Shim H, Kim S, Li Q, Reddy R, Mukherjee M, Xu Y, Wonsey D, Lee L, Dang C (2000) Deregulation of glucose transporter 1 and glycolytic gene expression by c-Myc. J Biol Chem 275: $21797-21800$

Parry D, Pedersen P (1983) Intracellular localization and properties of particulate hexokinase in the Novikoff ascites tumor. J Biol Chem 258: $10904-$ 10912
Rathmell J, Vander Heiden M, Harris M, Frauwirth K, Thompson C (2000) In the absence of extrinsic signals, nutrient utilization by lymphocytes is insufficient to maintain either cell size or viability. Mol Cell 6: 683-692

Reed B, Shade D, Alperovich F, Vang M (1990) 3T3-L1 adipocyte glucose transporter sequence and regulation of protein and mRNA expression by insulin, differentiation and glucose starvation. Arch Biochem Biophys 279: $261-274$

Rempel A, Mathupala S, Griffin C, Hawkins A, Pedersen P (1996) Glucose catabolism in cancer cells: amplification of the gene encoding type II hexokinase. Cancer Res 56: 2468-2471

Rivenzon-Segal D, Rushkin E, Polak-Charcon S, Degani H (2000) Glucose transporters and transport kinetics in retinoic acid differentiated T47D human breast cancer cells. Am J Physiol Endocrinol Metabol 279:E508E519

Shah G, Kaufmann S, Piorier G (1995) Detection of poly(ADP-ribose) polymerase and its apoptotic-specific fragment by a nonisotopic activitywestern blot technique. Anal Biochem 232: 251-254

Shim H, Chun Y, Lewis B, Dang C (1998) A unique glucose-dependent apoptotic pathway induced by c-Myc. Proc Natl Acad Sci USA 95: $1511-1516$

Sperandio S, Belle I, Bredesen D (2000) An alternative, nonapoptotic form of programmed cell death. Proc Natl Acad Sci USA 97: 14376-14381

Spitz D, Sim J, Ridnour L, Galoforo S, Lee Y (2000) Glucose deprivationinduced oxidative stress in human tumor cells: a fundamental defect in metabolism? Ann NY Acad Sci 899: 349-362

Tafani M, Minchenko D, Serroni A, Farber J (2001) Induction of the mitochondrial permeability transition mediates the killing of HeLa cells by staurosporine. Cancer Res 61: 2446-2459

Tannock I, Lee C (2001) Evidence against apoptosis as a major mechanism for reproductive cell death following treatment of cell lines with anticancer drugs. Br J Cancer 84: $100-105$

Vander Heiden M, Plas D, Rathmell J, Fox C, Harris M, Thompson C (2001) Growth factors can influence cell growth and survival through effects on glucose metabolism. Mol Cell Biol 21: 5899-5912

von der Crone S, Deppe C, Barthel A, Sasson S, Joost H, Schurmann A (2000) Glucose deprivation induces Akt-dependent synthesis and incorporation of Glut1, but not Glut4, into the plasma membrane of 3T3-L1 adipocytes. Eur J Biochem 79: $943-949$

Wahl R, Cody R, Hutchins G, Mudgett E (1991) Primary and metastatic breast carcinomas: initial clinical evaluation with PET with the radiolabelled glucose analogue 2-(F-18)-fluoro-2-deoxyglucose. Radiology 179: $765-770$

Waki A, Fujibayashi Y, Sadato N, Ishii Y, Yokoyama A (1997) Reassessment of FDG uptake in tumor cells: high FDG uptake as a reflection of oxygenindependent glycolysis dominant energy production. Nuclear Med Biol 24: $665-670$

Waki A, Kato H, Yano R, Sadato N, Yokoyama A, Ishii Y, Yonekura Y, Fujibayashi Y (1998) The importance of glucose transport activity as the ratelimiting step of 2-deoxyglucose uptake in tumor cells in vitro. Nuclear Med Biol 25: $593-597$

Warburg O (1956) On the origin of cancer cells. Science 123: 309-314

Weber G (1977) Enzymology of cancer cells. N Engl J Med 296: 541-551

Wick A, Drury D, Nakada H, Wolfe J (1957) Localization of the primary block produced by 2-deoxyglucose. J Biol Chem 224: $963-969$

Wilson J (1997) An introduction to the isoenzymes of mammalian hexokinase types I-III. Biochem Soc Transact 25: 103-107

Yamamoto T, Seino Y, Fukumoto H, Koh G, Yano H, Inagaki N, Yamada Y, Inoune K, Manabe T, Imura H (1990) Over expression of facilitative glucose transporter genes in human cancer. Biochem Biophys Res Commun 170: $223-230$

Younes M, Brown R, Mody D, Fernandez L, Laucricra R (1995) Glut1 expression in human breast carcinoma: correlation with known prognostic markers. Anticancer Res 15: 2895-2898

Younes M, Lechago L, Somoano J, Mosharaf M, Lechago J (1996) Wide distribution of the human erythrocyte glucose transporter Glut1 in human cancers. Cancer Res 56: 1164-1167

Zhong L, Sarafian T, Kane D, Charles A, Mah S, Edwards R, Bredesen D (1993) Bcl-2 inhibits death of central neural cells induced by multiple agents. Proc Natl Acad Sci USA 90: 4533-4537 